\title{
Improving Milk Quality for Dairy Goat Farm Development
}

\author{
L. Cyrillaa, ${ }^{\mathrm{a},}$, B. P. Purwanto ${ }^{\mathrm{b}}$, A. Atabany ${ }^{\mathrm{a}}$, D. A. Astuti ${ }^{\mathrm{c}}$, \& A. Sukmawati ${ }^{\mathrm{d}}$ \\ a Department of Animal Production and Technology, Faculty of Animal Science, Bogor Agricultural University \\ Jalan Agatis, Kampus IPB Darmaga Bogor 16680, Indonesia

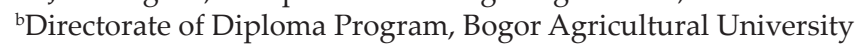 \\ Jalan Kumbang No. 14, Bogor 16151, Indonesia \\ 'Department of Nutrition and Feed Technology, Faculty of Animal Science, Bogor Agricultural University \\ Jalan Agatis, Kampus IPB Darmaga Bogor 16680, Indonesia \\ ${ }^{\mathrm{d}}$ Department of Management, Faculty of Economics and Management, Bogor Agricultural University \\ Jalan Kamper, Kampus IPB Darmaga Bogor 16680, Indonesia \\ (Received 28-05-2015; Reviewed 29-06-2015; Accepted 24-08-2015)
}

\begin{abstract}
The present study was designed to evaluate factors affecting goat's milk quality, consumer's satisfaction to goat's milk, and technical responses associated with goat's milk quality. Three farms having more than 100 dairy goats were purposively selected for the study. Thirty consumers were determined by using judgement sampling techniques to assess the satisfaction of consumer to goat's milk quality. Data were analyzed by using fishbone diagram and House of Quality matrix. The study revealed that milk quality produced by dairy goat farms met the standard quality of milk composition namely; specific gravity, total solid, fat, protein, and total solid non-fat. The main factors affecting goat milk quantity and quality were the quality of does, pregnancy status, number of kids per birth, shape and size of the udder, lactation length, and the health status of the goat. The attributes of goat's milk that were able to achieve customer's satisfaction targets were nutritional content, packaging size, and goat milk color. Technical responses that were major concern in ensuring goat's milk quality included goat breed quality and health conditions, skills and performances of farmers and employees, feed quality, farm equipment hygiene and completeness, cleanliness, and hygiene of livestock housing and environment. Technical response on livestock health condition was the first priority to be improved.
\end{abstract}

Key words: goat milk, consumer's satisfaction

\begin{abstract}
ABSTRAK
Penelitian ini bertujuan untuk mengevaluasi faktor yang mempengaruhi kualitas susu kambing, tingkat kepuasan konsumen, dan respons teknis yang terkait dengan kualitas susu kambing. Penelitian dilaksanakan di tiga peternakan kambing perah yang dipilih secara purposive, yaitu peternakan yang memiliki populasi lebih dari 100 ekor. Sampel konsumen untuk penilaian kepuasan terhadap susu kambing sebanyak 30 orang ditentukan menggunakan teknik judgment sampling. Analisis data menggunakan diagram tulang ikan dan matriks rumah mutu. Hasil penelitian menunjukkan bahwa kualitas susu kambing dari peternakan yang diteliti sudah memenuhi standar, khususnya dilihat dari parameter berat jenis, kadar lemak, bahan kering, protein, dan bahan kering tanpa lemak. Faktor utama yang mempengaruhi kuantitas dan kualitas susu kambing adalah kualitas bibit, status kebuntingan, jumlah anak per kelahiran, bentuk dan ukuran ambing, lama laktasi, dan status kesehatan ternak. Atribut kandungan gizi, ukuran kemasan, dan warna susu kambing sudah mampu mencapai target kepuasan konsumen. Respons teknis utama peternakan dalam menjamin kualitas susu kambing meliputi kualitas bibit dan kondisi kesehatan, keterampilan dan kinerja peternak dan karyawan, kualitas pakan, kebersihan dan kelengkapan peralatan peternakan, kebersihan dan higiene kandang dan lingkungannya. Respons teknis kualitas dan kondisi kesehatan ternak merupakan prioritas pertama untuk diperhatikan.
\end{abstract}

Kata kunci: susu kambing, kepuasan konsumen

*Corresponding author:

E-mail: luci usmar@yahoo.co.id; luci.wanto@gmail.com 


\section{INTRODUCTION}

Milk is one of the protein sources for humans. However, as cow's milk is not available or not affordable to millions of Indonesian people, family consumption of goat's milk as an alternative is important in the prevention of under-nutrition and malnutrition. People consider that milk, especially goat's milk, provide health benefit for them, and it greatly improves the diet of many rural families. Although a number of health effects have been attributed to consuming goat's milk, scientific evidence does not support most of the health claims.

Such situation provides opportunities for prospective dairy goat farms to develop and to supply milk in Indonesia (Ditjen Industri Agro dan Kimia 2009; Diwyanto \& Priyanti, 2009; Hibma, 2007). Yet market demand for goat's milk began to increase in the last few years, but they have not been met as the goat's milk production is still limited. This limitation is attributed to the low productivity of the existed dairy goats, and the lower population as well. One of the biggest problems faced by someone getting into the dairy goat business is recognizing that it is not a quick easy business to get into and operate. Benefits of goat's milk are more potent and better when compared to other milks on the market. Goat's milk benefits are superior to cow's milk, as it is richer than cow's milk in some important nutrients: vitamin A, niacin, choline, and inositol; it is poorer in folic acid. Moreover, in term of efficacy and benefits of goat's milk for health, goat's milk can also be taken as a skin care benefits, such as a face mask so that the face looks fresh, healthy, moist, not dull and dry, and can shrink pores. Finally, goat's milk is easier to digest, is less allergenic, and can be consumed by all age groups (Park, 2010). Therefore, the selling price of fresh goat milk is still quite high, namely between IDR 25,000-60,000/liter.

Dairy goat farms are aware that maintaining the good quality of goat's milk is important in order to maintain the consumer's confidence and the sustainability of their businesses. How farms maintain their products to meet standardized milk quality is still questionable. Therefore, it is deemed necessary to implement research program related to the topic needs to repond to the questions.

The objectives of the study were to evaluate the quality of the fresh goat's milk produced by dairy goat farms, as well as to evaluate factors affecting the quality of fresh goat milk, and customer requirements to goat's milk. It is expected that the study will be beneficial to all parties associated with the development of dairy goat farms, especially in the City and District of Bogor.

\section{METHODS}

The study was carried out in three dairy goat farms in the City and District of Bogor, West Java. Samples were collected purposively from farms having more than 100 goats. Samples of 30 consumers were deter- mined by using judgment sampling techniques to assess their satisfaction on goat's milk. Judgment sampling is a common nonprobability method. The sample was selected based upon judgment, and this technique was an extension of convenience sampling (Ishak \& Bakar, 2014).

The data were collected by using questionnaire and checklist forms which contained the characteristics of dairy goats (i.e. breed, age, milk production, pregnancy status, and lactation period), goat farms characteristics (i.e. location altitude, ambient temperature, humidity, goat population, livestock composition, type of feed ingredients, housing type, livestock environment, farmer's experience, and farm goal), consumer's attitudes toward goat milk purchasing (i.e. quantity, frequency, and place), consumer's assessment for goat milk attributes (consumer's satisfaction).

The analytical method was based on the Fishbone Diagram (Maisana et al., 2014; Marimin, 2004; Varsha et al. 2015; Wong, 2011) and House of Quality (Quality Function Deployment, QFD) (Gaspersz, 2007; Rahmawan et al., 2014). The fishbone diagram identifies many possible causes for an effect or problem. It can be used to structure a brainstorming session. It immediately sorts ideas into useful categories. The Fishbone Diagram method is illustrated by a fish, where its head contains issues or topics to be analyzed, and the fishbone contain the main factors that affect the issue. If the causes of problem are identified, then the actions and corrective measures will be easier to be carried out.

Quality Function Deployment (QFD) is defined as a process or a structured mechanism for determining customer needs and translate those needs into relevant technical requirements, which each functional area and level of the organization can understand and take follow up actions (Gaspersz, 2007; Suryaningrat et al., 2010; Wang, 2013). QFD is a method to improve the quality of goods or services based on the consumer's needs, and to accomplish to satisfy or even delight the customers. Once we have prioritized the attributes and qualities, QFD deploys them to the appropriate organizational function for action (Marimin 2004; Ulya 2012). The product development team uses the House of Quality (HOQ) matrix to initiate a Quality Function Deployment (QFD) process. This matrix consists of two main parts. The horizontal matrix containing information about customer needs, it is called the customer table, whereas the vertical matrix containing information how the organization will meet the challenges of providing products that delight the customer, it is called technical table.

Steps in making the HOQ are: 1) identifying the customer's expectation, 2) identification of the technical responses in providing products, 3) determine the relationship between the customer's expectation with technical responses, 4) determine the company's performance appraisal, 5) compares customer's satisfaction with the product generated by the product of the competitors, 6) provide an assessment of influence between one technical response with another. 


\section{RESULTS AND DISCUSSION}

\section{Factors Affecting Goat Milk Production and Its Quality}

Fresh goat's milk is a yellowish-white liquid with a slightly sweet taste and has a distinctive aroma. Fresh milk is highly perishable. Factors influencing milk quality are the handling of animals, especially feeding; handling of milk: before, during, and after milking; the cooling process, transporting, pasteurization process, packaging, and processing equipment as well. Pasteurized goat's milk will not be allowed to contain pathogens or foreign substances such as antibiotics, antiseptics, or pesticide residues. Goat's milk is generally similar to cow's milk, but the amounts of shorter-chain fatty acids in goat's milk fat significantly different from cow's milk. Goaty flavor is attributable to caproic, caprylic, and capric acids, which are present at high levels in goat's milk fat and subject to release from fat globule membranes by lipases if improper milking and processing are practiced (Park, 2010).

Currently, Indonesia has no specific standard for goat's milk, only herd quality standard for crossed goat of Etawa (BSN, 2008) and Kaligesing goat (Kementan, 2010) available. National Standardization Agency (BSN) issued SNI 3141.1:2011 which was actually the revised version of SNI 01-3141-1998 to standardize fresh milk (Table 1). The current reference standard applicable for goat's milk quality is the Thai Agricultural Standard for Raw Goat Milk issued by the National Bureau of
Agricultural Commodity and Food Standards Ministry of Agriculture and Cooperatives of Thailand (Table 1).

Based on the goat's milk quality analysis (Table 2) it was revealed that goat's milk produced by dairy goat farms had met Indonesia fresh milk standard (SNI 3141.1:2011) and Thai Agricultural Standard of Raw Goat Milk (TAS, 2008) as well, particularly in the basic components, i.e., specific gravity, total solid, fat, protein, and total solid non-fat. Moreover, further analysis of its fat and protein contents, goat's milk from those farms could be classified into the premium category.

Fishbone diagram (Figure 1) shows factors affecting the quantity and quality of goat's milk. These factors include:

Aspects of human resources. Farmer is the manager of his/her goat farm, how she/he will develop his/her dairy goat farm into successful one will depend on its achievements in making decisions. The ability and

Table 1. Fresh milk quality standard

\begin{tabular}{|c|c|c|c|c|}
\hline \multirow{2}{*}{ Parameter } & \multirow{2}{*}{$\begin{array}{c}\text { SNI } \\
3141.1: 2011^{1}\end{array}$} & \multicolumn{3}{|c|}{ Thai Agricultural Standard $6006^{2}$} \\
\hline & & Premium & Good & Standard \\
\hline $\begin{array}{l}\text { Specific gravity } \\
\left(\text { at } 27^{\circ} \mathrm{C}\right)\end{array}$ & Min 1.0270 & - & & \\
\hline Fat $(\%)$ & Min 3.0 & $>4$ & $>3.5$ to 4 & 3.25 to 3.5 \\
\hline Total solid non-fat (\%) & Min 7.8 & - & - & 8.25 \\
\hline Protein $(\%)$ & $\operatorname{Min} 2.8$ & $>3.7$ & $>3.4$ to 3.7 & 3.1 to 3.4 \\
\hline
\end{tabular}

Note: ${ }^{1}$ BSN (2011), ${ }^{2}$ TAS (2008)

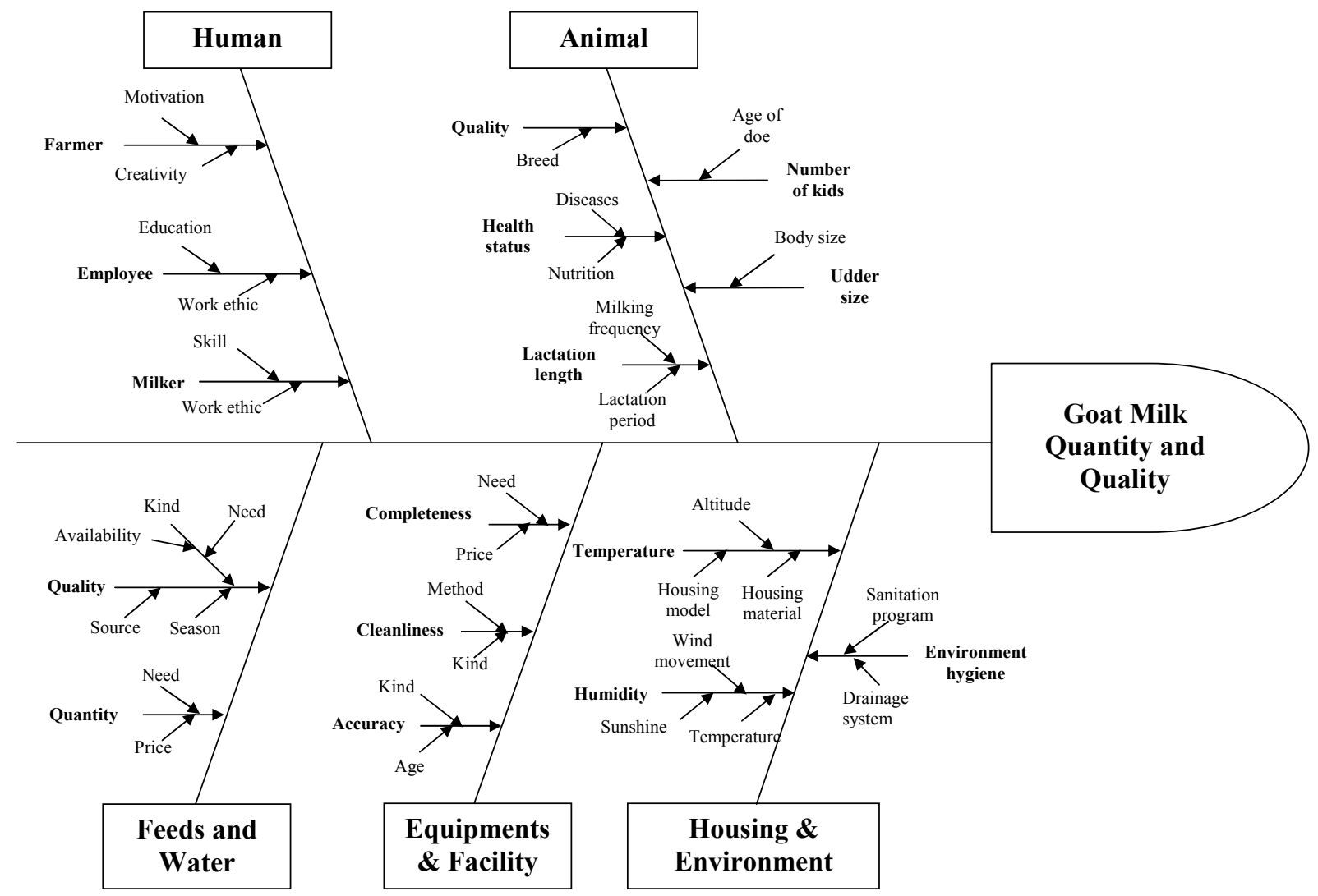

Figure 1. Factors affect goat milk quality 
Table 2. Goat's milk quality of the analyzed farms

\begin{tabular}{lccc}
\hline Description & Farm A & Farm B & Farm C \\
\hline Dairy goat' breed & Saanen & PE \& Saanen & Etawa \& PE \\
Population of lactation does (head) & 90 & 22 & 44 \\
Total milk production (L/d) & $110 \pm 30$ & $22.2 \pm 2.50$ & $40.5 \pm 7.50$ \\
Average milk production (L/head/d) & $1.2 \pm 0.30$ & $1.01 \pm 0.25$ & $0.92 \pm 0.20$ \\
Quality parameter* & & & \\
Specific gravity & $1.0295 \pm 0.0003$ & $1.0300 \pm 0.0002$ & $1.0300 \pm 0.0002$ \\
Total solid (\%) & $15.88 \pm 0.02$ & $14.78 \pm 0.01$ & $14.40 \pm 10.02$ \\
Fat (\%) & $6.6 \pm 0.40$ & $5.6 \pm 0.50$ & $5.3 \pm 0.50$ \\
Protein (\%) & $3.70 \pm 0.06$ & $4.09 \pm 0.03$ & $3.70 \pm 0.04$ \\
Total solid non-fat (\%) & $9.28 \pm 0.04$ & $9.18 \pm 0.03$ & $9.11 \pm 0.04$ \\
\hline
\end{tabular}

Note: *Analyzed in Dairy Production Laboratory, Department of Animal Production and Technology, Faculty of Animal Science Bogor Agricultural University (2014).

accuracy of decision to be made by farmers are greatly influenced by their motivation and creativity (Edwards \& Shultz, 2005). The farmers who were assessed generally had a high entrepreneurial spirit, which was reflected in their creativities, innovativeness, discipline, highly motivated, leadership, and they did not dare to take risks. They should quickly see the opportunities to grow their business efficiencies. Those dairy goat farms never or very often replace the experienced milker with the new employee when milking routine is wellestablished and producing desired results. Substitution will cause stress because of goats are not easily adapt to the drastic changed of environmental conditions (Butler et al., 2011). Skillful and experiences are the primary requirements in selecting milkers to make the goat feel comfortable so milk production would not be affected. In addition, the prospective candidates must be healthy as they might transfer their contagious disease, such as tuberculosis, into goats. Factors of discipline and skills of employees in handling of goats are very important in the recruitment of employees. The goats must be raised and treated with respect to the fact that they can feel fear and pain (Alcedo et al., 2014).

Livestock aspect. The major breeds of dairy goats on farms studied were Saanen, Etawa or Etawa crossbred (which latter on will be shortened into PE). Saanen milk production is higher than the PE goats (Ciappesoni et al., 2004; Costa et al., 2014; Zain, 2013). Specific gravity of Saanen goat's milk raised by farm A was lower compare to the other two farms. These results are consistent with the results of Zain (2013) and Costa et al. (2014) (Table 3). The age of goats of the dairy goat farms were generally between 2.5-3 years (I2 - I3), with the second and third lactation stage. On average each dairy goat produced two kids in each kidding. Milking was done 2 times a day. Timing of mating generally 3 months after their goats gave birth or after the first estrous cycle appeared to push their goats for kidding three times in the two years.

Aspects of feeding and drinking water. To maintain optimum milk production and good health, the farmers fed their goats with a balanced diet for energy, protein,
Table 3. Goat milk quality from previous research

\begin{tabular}{lcc}
\hline \multirow{2}{*}{ Milk quality parameter } & \multicolumn{2}{c}{ Dairy goat breeds } \\
\cline { 2 - 3 } & Etawa Crossbred & Saanen \\
\hline Specific gravity & $1.0258-1.0264^{2)}$ & $1.030 \pm 0.08^{3)}$ \\
Protein (\%) & $7.03-7.53^{2)}$ & $3.15 \pm 0.01^{3)}$ \\
Fat (\%) & $6.27-7.60^{2)}$ & $3.55 \pm 0.21^{3)}$ \\
Total solid (\%) & $14.0678-14.0978^{1)}$ & - \\
Total solid non-fat $(\%)$ & $8.6517-8.6556^{1)}$ & - \\
\hline
\end{tabular}

Note: ${ }^{1)}$ Wibowo et al. (2013); ${ }^{2)}$ Zain (2013); ${ }^{3)}$ Costa et al. (2014).

minerals, and vitamins, according to their needs. Feed nutrients are used to grow, reproduction, lactation, and movement. The composition of forage and concentrates must be balanced, and three kinds of forages such as grass, legumes, and pasture should constitute a majority of the daily diet (Fuah \& Pattie, 2013; Morand et al., 2007; Sodiq \& Setianto, 2009).

Farmers usually feed their goats with variety of feeds. Farm A provides their goats with Napier grass (Pennisetum purpureum), field grass and other forages, and concentrates (i.e. dreg of beer, tofu waste or bran) as well. On the average of 4-5 kg/day of forage and approximately $400-500 \mathrm{~g} /$ day concentrates are given as their daily intake. Whereas farm $\mathrm{B}$ gives concentrate mixed with cassava, bran, pulp, and dry onion skins they purchased from markets around their farms in Bogor. In addition, forages consisted of grass and leaves of cassava, calliandra, gliricidia, and indigofera are also given. Finally the farm $C$ feeds its goats with forages and concentrates. Forages are given in the form of Napier grass (P. purpureum). In addition, a typical concentrate contains soybean cake waste, tofu waste, palm waste, black cumin (Habatussauda), and ready-made concentrate are also given.

Facilities and equipment. Existing facilities and equipment at the dairy goat farm is milk buckets, funnels, filter, rags, napkins, hoes, sickles and shovels, nail clippers, medical equipment, and drug. To guarantee the good quality of goat's milk the equipment and technology should follow standardizes milking procedures. 
Farmers always control all the milking equipment and other facilities regularly. Unclean facilities will be harmful to goats due to the contamination caused by microbial pathogens, chemicals, and physical solvents directly and indirectly (Gustiani, 2009; Olechnowicz \& Sobek, 2008; Taufik et al., 2011). To minimize the occurrence of microbial contamination in milk, the milk packaging rooms in all farms studied were located quite close to the milking parlor.

Housing and environmental aspects. The dairy goat farms studied are not easily accessible as they are located far from the highway. The elevation of the farm locations are generally more than $500 \mathrm{~m}$ above sea level. Goat's sheds are made in accordance with technical requirement, particularly enable to provide comfort and healthy environment, and good milk productivity. Farmers use housing materials which is easily available in the surrounding area. Planting trees around the housing at farm A and B make housing more airy, in addition to withstand the wind. Good ventilation, lighting, and comfort are factors to be considered to improve the performance of dairy goats (Alcedo et al., 2014; Sabapara et al., 2014). In order to minimize the contamination caused by immediate environment pollution for dairy goats, the farms were built away from industrial plants as sources of pollution, congested highways, or pest breeding sites such as landfills, and other source of wastes.

\section{Consumer's Satisfaction on Goat's Milk}

Trend of research results on the level of consumer interests to goat's milk show that attributes for nutrient content of goat's milk is very important for consumers. Consumers need important information on the nutrient content and expiration dates of the goat's milk; they must be printed clearly on its packages. It is very important to ensure the consumers that the products they consume are safe and healthy (Bhuiyan \& Nahar, 2013; Shahroudi \& Naimi, 2014).

The price of goat's milk produced in farm A is IDR $30,000 /$ liter, in farm B is IDR 27,500/ liter, and in farm $\mathrm{C}$ is IDR 35,000/liter. Packaging size of goat's milk sold to the consumer is $200 \mathrm{cc}$. For consumers, the relatively expensive price of goat milk if compared to cow's milk would not be problem for them as long as they are convinced that consuming goat milk is beneficial for them. The consumers expect that dairy goat farmers guarantee the availability of goat's milk at any time.

Table 4 shows consumers' satisfaction on the attributes of nutritional content, flavor, aroma, color, packaging design, package size, and price of goat milk produced by farm A. Similar assessments were also given by consumers for goat's milk produced by farm C. While for goat's milk produced by farm B, the study revealed that consumers were satisfied with similar attribute own by farm A and B, except on its practicality for consumption.

Goat milk prices at farm B was relatively lower than the other two farms. This was due to that farmer B did not put labels in its packaging, whereas the other two farms have implemented this. Goat's milk products of farm B are sold in 200 cc size of plastic packs. In addition, farm B does not only perform direct selling for individual consumers but also for retailers or distributors that resell the milk using their own packages. There are opportunities for farm B to sell its milk production at the same price with the other two farms or even higher if the farm improves the design of its packages to suit its customer's expectations.

\section{Technical Response of Dairy Goat Farms}

Technical response is the process that deals with attributes expected by goat's milk consumers. Relationship between consumer's expectations and technical responses were using symbols to express the strength of the relationship. Analysis on the technical response is required to enable farmers to meet consumer's expectations, to improve the customer satisfaction for their products (Ates \& Ceylan, 2010; Edwards \& Shultz, 2005). The data collected by using an interview schedule of the farm management showed that technical response was applied on their dairy goat farms. According to them, their major concern was to ensure the good quality of their goat milk products, which include milk quality, health conditions of goats, skills and performance of farmers and their employees, animal feed, hygienic and completeness of farm equipment, as well as the

Table 4. Goat milk consumer' satisfaction of the analyzed farms

\begin{tabular}{lcccccc}
\hline \multirow{2}{*}{ Attributes } & \multicolumn{2}{c}{ Farm A } & \multicolumn{2}{c}{ Farm B } & \multicolumn{2}{c}{ Farm C } \\
\cline { 2 - 7 } & $\begin{array}{c}\text { Consumer' } \\
\text { satisfaction }\end{array}$ & Percentage & $\begin{array}{c}\text { Consumer } \\
\text { satisfaction }\end{array}$ & Percentage & $\begin{array}{c}\text { Consumer' } \\
\text { satisfaction }\end{array}$ & \begin{tabular}{c} 
Percentage \\
\hline Nutritional content
\end{tabular} \\
Flavor & 4 & 96.3 & 4 & 96.9 & 4 & 99.2 \\
Expiration date information & 3 & 88.1 & 4 & 88.5 & 4 & 91.2 \\
Ease of obtaining & 3 & 68.9 & 3 & 74.6 & 3 & 69.6 \\
Aroma & 4 & 68.9 & 3 & 80 & 3 & 69.6 \\
Consume practicality & 3 & 88.9 & 4 & 91.5 & 4 & 90.4 \\
Packaging design & 4 & 81.9 & 4 & 86.2 & 3 & 80 \\
Packaging size & 4 & 88.9 & 3 & 75.4 & 4 & 90.4 \\
Price & 4 & 88.1 & 4 & 86.9 & 4 & 90.4 \\
Color & 4 & 88.1 & 4 & 86.2 & 4 & 91.2 \\
\hline
\end{tabular}


clean and good quality of housing and the environment. Technical response for handling milk quality has been implemented by dairy goat farmers starts from milking stage, up to process and they are ready to serve the customers in packages. Farmers must be able to guarantee the hygienic, health, and safety of goat's milk they produced, as they have been very concerned about them.

Table 5 shows that technical response of milk quality has a strong relationship with the technical response of the quality and health conditions of the goats. The good quality of milk will correspond with the quality and health of goats. Technical responses of milk quality also has a strong relationship with the skills and performance of farmers and employees. It means the quality of milk corresponds to the skills and performance of farmers and their employees.

Other technical responses are the quality of animal feed, hygienic and completeness of farm equipment, and the clean and good quality of pens and the environ- ment also have a strong and positive relationship with the technical response, particularly for the quality of milk. It is proved that technical response for milk quality is highly dependent on other technical responses (Sabapara et al., 2014).

\section{Goat's Milk House of Quality}

House of Quality (HoQ) is one of Quality Function Deployment Matrix to explain the expectations of consumers and how to meet these expectations (Gaspersz, 2007; Al-Marsumi, 2009). The ability of producers to meet consumer's expectations will be reflected in the ratio between the company target and level of customer's satisfaction. Expectations reflect both past and current product evaluation and use experiences (Midau et al., 2010). Goat's Milk House of Quality (Figure 2) shows the highest customer's satisfaction scores for goat milk. The highest scores were given to the attributes of

Table 5. Relations between the technical response of goat milk production

\begin{tabular}{|c|c|c|c|}
\hline Technical response & Related technical response & Correlation & Sign \\
\hline \multirow[t]{5}{*}{ Milk quality } & $\begin{array}{l}\text { Livestock quality and health } \\
\text { condition }\end{array}$ & $\begin{array}{l}\text { Strong positive, quality of milk will increase if the quality } \\
\text { and animal health increased }\end{array}$ & ++ \\
\hline & $\begin{array}{l}\text { Skills and performance of } \\
\text { farmers and their employees }\end{array}$ & $\begin{array}{l}\text { Strong positive, the quality of milk will increase if skills and } \\
\text { performance of farmers and their employees increased }\end{array}$ & ++ \\
\hline & The quality of feed & $\begin{array}{l}\text { Strong positive, the quality of milk will increase if quality of } \\
\text { feed increased }\end{array}$ & ++ \\
\hline & $\begin{array}{l}\text { Hygiene and completeness of } \\
\text { farm equipment }\end{array}$ & $\begin{array}{l}\text { Strong positive, the quality of milk will increase if hygiene } \\
\text { and completeness of farm equipment increased }\end{array}$ & ++ \\
\hline & $\begin{array}{l}\text { Cleanliness and healthy } \\
\text { housing environment }\end{array}$ & $\begin{array}{l}\text { Strong positive, the quality of milk will increase if cleanliness } \\
\text { and healthy housing environment increased }\end{array}$ & ++ \\
\hline \multirow[t]{4}{*}{$\begin{array}{l}\text { Skills and performance } \\
\text { of farmers and their } \\
\text { employees }\end{array}$} & $\begin{array}{l}\text { Livestock quality and health } \\
\text { condition }\end{array}$ & $\begin{array}{l}\text { Strong positive, livestock quality and health condition will } \\
\text { be good if farmer and its employee had good skill and per- } \\
\text { formance }\end{array}$ & ++ \\
\hline & The quality of feed & $\begin{array}{l}\text { Strong positive, skills and performance of farmers and their } \\
\text { employees will greatly affect the quality of feed }\end{array}$ & ++ \\
\hline & $\begin{array}{l}\text { Hygiene and completeness of } \\
\text { farm equipment }\end{array}$ & $\begin{array}{l}\text { Strong positive, skills and performance of farmer and their } \\
\text { employees will greatly affect the hygiene and completeness } \\
\text { of farm equipment }\end{array}$ & ++ \\
\hline & $\begin{array}{l}\text { Cleanliness and healthy } \\
\text { housing environment }\end{array}$ & $\begin{array}{l}\text { Strong positive, skills and performance of farmer and their } \\
\text { employees will greatly affect the cleanliness and healthy } \\
\text { housing environment }\end{array}$ & ++ \\
\hline \multirow[t]{3}{*}{$\begin{array}{l}\text { Livestock quality and } \\
\text { health status }\end{array}$} & The quality of feed & $\begin{array}{l}\text { Strong positive, the quality of feed will greatly affect the } \\
\text { quality and health conditions of livestock }\end{array}$ & ++ \\
\hline & $\begin{array}{l}\text { Hygiene and completeness of } \\
\text { farm equipment }\end{array}$ & $\begin{array}{l}\text { Positive, hygiene and completeness of farm equipment will } \\
\text { affect the quality and health conditions of livestock }\end{array}$ & + \\
\hline & $\begin{array}{l}\text { Cleanliness and healthy } \\
\text { housing environment }\end{array}$ & $\begin{array}{l}\text { Strong positive, cleanliness and healthy housing environ- } \\
\text { ment will greatly affect the quality and health conditions of } \\
\text { livestock }\end{array}$ & ++ \\
\hline \multirow[t]{2}{*}{ Quality of feed } & $\begin{array}{l}\text { Hygiene and completeness of } \\
\text { farm equipment }\end{array}$ & $\begin{array}{l}\text { Positive, the quality of feed would be guaranteed by the pres- } \\
\text { ervation of cleanliness and completeness of farm equipment }\end{array}$ & + \\
\hline & $\begin{array}{l}\text { Cleanliness and healthy } \\
\text { housing environment }\end{array}$ & $\begin{array}{l}\text { Positive, the quality of feed would be guaranteed by the pres- } \\
\text { ervation of cleanliness and healthy housing and its environ- } \\
\text { ment }\end{array}$ & + \\
\hline $\begin{array}{l}\text { Cleanliness and } \\
\text { hygiene of housing and } \\
\text { environment }\end{array}$ & $\begin{array}{l}\text { Hygiene and completeness of } \\
\text { farm equipment }\end{array}$ & $\begin{array}{l}\text { Positive, hygiene and completeness of farm equipment will } \\
\text { be assured with the preservation of cleanliness and hygiene } \\
\text { housing and its environment }\end{array}$ & + \\
\hline
\end{tabular}

Note: ++ : Strong positive relationship; + : Positive relationship 


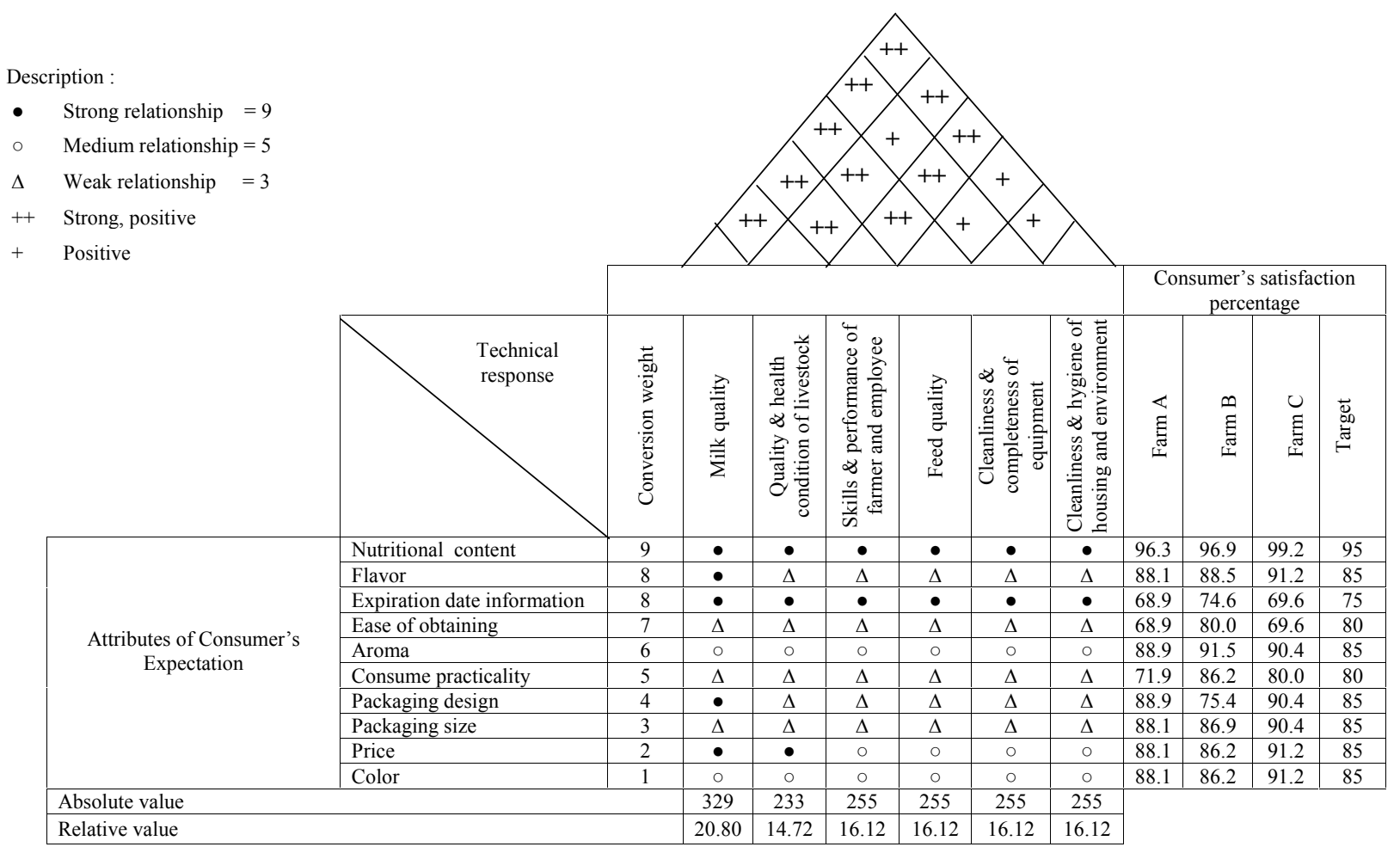

Figure 2. Goat milk house of quality

nutrient content, it means that farmers had been able to achieve the targeted expectation for consumer's satisfaction (the ratio is greater than one). Other attributes that reached the targets were the packaging size and color of goat's milk. Efforts must be made by dairy-goat farmers to achieve other customer's satisfaction attributes by improving their products.

Figure 2 shows the relationship between technical responses to consumer's expectations. Based on the data analyzed it was revealed that the technical response for the quality and health condition of goats was the first priority for improvement, as its relative value was rated 14.72 percent, the lowest score. Based on their experiences, the dairy goat farmers are aware of and understand the importance of keeping their goats always in good health condition to ensure the quality of milk produced to sustain their businesses.

\section{CONCLUSION}

Dairy goat farms development in Bogor Regency is feasible with the support of dairy goat farms that have been there all along. The goat's milk produced on farms studied already met the standards of goat's milk quality, and could be classified into the premium category. The main factors affecting goat's milk quantity and qualities were doe's quality, pregnancy status, the number of kids per birth, shape and size of the udder, lactation length, and goat's health status. Consumers were satisfied with the important attributes of goat's milk. However, to further ensure the fulfillment of the expectations of consumers about the quality of goat's milk, farmers still need to make improvements in the quality and the health condition of the livestock.

\section{REFERENCES}

Alcedo, M. J., K. Ito \& K. Maeda. 2014. Creating animal welfare assessment method for backyard goat production in the Philippines using stockmanship competence as proxy indicator. IJLP 5:173-180. http://dx.doi.org/10.5897/ IJLP2014.0217

Al-Marsumi, M. 2009. Total quality management in the top rank of the dairy industry in Jordan. JJMIE 3: 47- 58

Ates, H. \& M. Ceylan. 2010. Effects of socio-economic factors on the consumption of milk, youghurt, and cheese. Brit. Food J. 112: 234-250.

Bhuiyan, M. N. K. \& M. A. Nahar. 2013. Consumer satisfaction through the positioning of fundamental consumer value ingredients can enhance the opportunity of green marketing. European Journal of Business and Management 5: 2735.

[BSN] Badan Standardisasi Nasional. 2008. SNI 7352:2008 : Bibit Kambing Peranakan Etawa (PE). Badan Standardisasi Nasional, Jakarta.

[BSN] Badan Standarisasi Nasional. 2011. SNI 3141.1:2011. Susu segar. Standard Nasional Indonesia, Jakarta.

Butler, G., J. H. Nielsen, M. K. Larsen, B. Rehberger, S. Stergiadis, A. Canever \& C. Leifert. 2011. The effects of dairy management and processing on quality characteristics of milk and dairy products. NJAS - Wageningen Journal of Life Sciences 58: 97-102

Ciappesoni, G., J. Přibyl, M. Milerski \& V. Mareš. 2004. Factors affecting goat milk yield and its composition. Czech J. Anim. Sci. 49: 465-473

Costa, W. K. A. d., E. L .d. Souza, E. M. Beltrão-Filho, G. K. V. Vasconcelos, T. Santi-Gadelha, \& C. A. d. Almeida Gadelha 2014. Comparative protein composition analysis of goat milk produced by the Alpine and Saanen breeds in Northeastern Brazil and related antibacterial activities. PLoS ONE 9: e93361. http://dx.doi.org/10.1371/journal. pone. 0093361

Ditjen Industri Agro dan Kimia. 2009. Road Map Industri Susu. 
Departemen Perindustrian Republik Indonesia, Jakarta.

Diwyanto, K. \& A. Priyanti. 2009. Pengembangan industri peternakan berbasis sumber daya lokal. Jurnal Pengembangan Inovasi Pertanian 2: 208-228

Edwards, M. R. \& C. J. Shultz. 2005. Reframing agribusiness: moving from farm to market centric. Journal of Agribusiness 23: 57-73

Erkarslan, Ö. \& H. Yilmaz. 2011. Optimization of product design through quality function deployment and analytical hierarchy process: case study of a ceramic washbasin. METU JFA 28: 1-22. http://dx.doi.org/10.4305/METU. JFA.2011.1.1

Fuah, A. M. \& W. A. Pattie. 2013. Productivity of local goats supplemented with Acacia villosa and Coripha gebanga. Med. Pet. 36: 1-78. http://dx.doi.org/10.5398/medpet.2013.36.1.40

Gaspersz, V. 2007. Lean Six Sigma for Manufacturing and Service Industry. Gramedia, Jakarta.

Gustiani, E. 2009. Pengendalian cemaran mikroba pada bahan pangan asal ternak (daging dan susu) mulai dari peternakan sampai dihidangkan. Journal Litbang Pertanian, 28: 96-100.

Hibma J. 2007. Marketing "value added" dairy goat products: find a niche and fill it. Dairy Goat Journal 85: 14-16.

Ishak, N. M. \& A. Y. A. Bakar. 2014. Developing sampling frame for case study: challenges and conditions. World Journal of Education 4: 29-35. http://dx.doi.org/10.5430/wje.v4n3p29

[Kementan] Kementerian Pertanian. 2010. Keputusan Menteri Pertanian Nomor 2591/Kpts/PD.400/7/2010 tentang Penetapan Galur Kambing Kaligesing. Kementan RI, Jakarta.

Maisana, Z., Hartoyo, S., Fahmi , I. E Wijaya, H. 2014. Pendekatan total quality management produk broiler tolakan. Jurnal Manajemen \& Agribisnis 9: 163-172.

Marimin. 2004. Pengambilan Keputusan Kriteria Majemuk. Grasindo, Jakarta.

Midau, A., A. Kibon, M. S. Morrupa \& C. Augustine. 2010. Acceptability and consumption of goat milk in Adamawa State, Nigeria: a case study of Mubi North and Mubi South local government areas. J. Agric. Soc. Sci. 6: 11-13.

Morand-Fehr, P., V. Fedele, M. Decandia, Y. le Frileux. 2007. Influence of farming and feeding systems on composition and quality of goat and sheep milk. Small Rum. Res. 68: 20-34. http://dx.doi.org/10.1016/j.smallrumres.2006.09.019

Olechnowicz J. \& Z. Sobek. 2008. Factors of variation influencing production level, SCC and basic milk composition in dairy goats. J. Anim. and Feed Sci. 17: 41-49.

Ozawa, T., K. Mukuda, M. Fujita \& J. Nishitani. 2009. Goat milk acceptance and promotion methods in Japan: The questionnaire survey to middle class households. J. Anim. Sci. 80: 212-219. http://dx.doi.org/10.1111/j.17400929.2008.00611.x
Park, Y. W. 2010. Goat Milk Products: Quality, Composition, Processing, Marketing. In: W.G. Pond \& N. Bell (Eds). Encyclopedia of Animal Science. $2^{\text {nd }}$ Edition. Taylor and Francis. CRC Press. Boca Raton, FL.

Rahmawan, A., Sugiono, Chen, C. 2014. Aplikasi teknik quality function deployment dan lean manufacture untuk minimisasi waste. JEMIS 2: 1-6.

Sabapara, G. P., V. B. Kharadi, L. M. Sorthiya, \& D. C. Patel. 2014. Housing, health care and milking management practices followed by goat owners in Navsari district of $\mathrm{Gu}-$ jarat. Sch. J. Agric. Vet. Sci. 1: 164-167.

Shahroudi, K. \& Naimi, S. S. 2014. The impact of brand image on customer satisfaction and loyalty intention (case study: consumer of hygiene products). International Journal of Engineering Innovation \& Research 3: 57-61.

Sodiq, A. \& N. A. Setianto. 2009. Production system of Peranakan Etawah goat under application of feed technology: productivity and economic efficiency. J. Anim. Prod. 11: 202-208

Suryaningrat, I.B., Djumarti, E. Ruriani \& I. Kurniawati. 2010. Aplikasi metode quality function deployment (QFD) untuk peningkatan kualitas mie jagung. AGROTEK 4: 8-17.

[TAS] Thai Agricultural Standard 6006. 2008. Standard for Raw Goat Milk. National Bureau of Agricultural Commodity and Food Standards Ministry of Agriculture and Cooperatives Thailand.

Taufik, E., G. Hildebrandt, J. N. Kleer, T. I. Wirjantoro, K. Kreausukon, K. H. Zessin, P. O. Baumann \& F. H. Pasaribu. 2011. Microbiological quality of raw goat milk in Bogor, Indonesia. Med. Pet. 32: 105-111. http://dx.doi. org/10.5398/medpet.2011.34.2.105

Ulya, M. 2012. Identifikasi persyaratan pelanggan terhadap produk tahu. AGROINTEK 6: 72-78.

Varsha, S. W., Siddhi, H. P., Kachave, R. N. \& Chaudhari, S. R. 2015. A review on: fishbone diagram. World Journal of Pharmaceutical Research 4: 638-645.

Wang, W. S. 2013. Exploring the quality function deployment method: a case study on the restaurant industry in Taiwan. International Journal of Research Studies in Management 2: 3-20. http://dx.doi.org/10.5861/ijrsm.2012.160

Wibowo, P. A., T. Y. Astuti \& P. Soediarto. 2013. Kajian total solid (TS) dan solid non-fat (SNF) susu kambing peranakan ettawa (PE) pada satu periode laktasi. Jurnal Ilmiah Peternakan Universitas Jenderal Soedirman 1: 214-221.

Wong, K. C. 2011. Using an Ishikawa diagram as a tool to assist memory and retrieval of relevant medical cases from the medical literature. J. Med. Case Reports 5: 120. http:// dx.doi.org/10.1186/1752-1947-5-120

Zain, W. N. H. 2013. Kualitas susu kambing segar di peternakan Umban Sari dan Alam Raya Kota Pekanbaru. J. Peternakan 10: $24-30$. 